\title{
PENGARUH KEPEMILIKAN MANAJERIAL DAN KEPEMILIKAN INSTITUSIONAL TERHADAP FUTURE EARNINGS RESPONSE COEFFICIENT DENGAN KESEMPATAN PERTUMBUHAN SEBAGAI VARIABEL MODERASI
}

\author{
Henny $^{1}$, Thio Lie Sha ${ }^{2}$ \\ ${ }^{1}$ Program Studi Akuntansi, Universitas Tarumanagara Jakarta \\ Email: henny@fe.untar.ac.id \\ ${ }^{2}$ Program Studi Akuntansi, Universitas Tarumanagara Jakarta \\ Email:thios@fe.untar.ac.id
}

Masuk : 28-03-2020, revisi: 19-08-2020, diterima untuk diterbitkan : 20-08-2020

\begin{abstract}
ABSTRAK
Tujuan penelitian ini adalah untuk memperoleh bukti empiris mengenai pengaruh kepemilikan manajerial dan kepemilikan institusional terhadap future earnings response coefficient dengan kesempatan pertumbuhan sebagai variabel moderasi pada perusahaan manufaktur di Bursa Efek Indonesia. Populasi dalam penelitian ini merupakan perusahaan manufaktur periode 2010-2017 yang memenuhi kriteria penelitian, sehingga penarikan sampelnya sebanyak 36 perusahaan manufaktur dengan menggunakan metode purposive sampling. Analisis yang digunakan dalam penelitian ini adalah moderated regression analysis dengan SPSS. Hasil penelitian ini adalah kesempatan pertumbuhan sebagai variabel moderasi memperkuat hubungan positif kepemilikan manajerial dan kepemilikan institusional terhadap future earnings response coefficient, sedangkan kepemilikan manajerial dan kepemilikan institusional tidak berpengaruh langsung terhadap future earnings response coefficient.
\end{abstract}

Kata Kunci: Kepemilikan manajerial, kepemilikan institusional, future earnings response coefficient, kesempatan Pertumbuhan

\section{ABSTRACT}

The purpose of this study is to obtain empirical evidence about the effect of managerial ownership and institutional ownership on future earnings response coefficient with growth opportunities as a moderating variable in manufacturing companies in the Indonesia Stock Exchange. The population in this study is a manufacturing company for the period 2010-2017 that meets the research criteria, so that the sample is 36 manufacturing companies using the purposive sampling method. The analysis used in this study is moderated regression analysis with SPSS. The results of this study is growth opportunities as a moderating variable to strengthen the positive relationship of managerial ownership and institutional ownership on future earnings response coefficient, while managerial ownership and institutional ownership do not directly influence future earnings response coefficient.

Keywords: Managerial ownership, institutional ownership, future earnings response coefficient, growth opportunities.

\section{PENDAHULUAN}

\section{Latar Belakang}

Investor yang merupakan salah satu stakeholder cenderung terkonsentrasi pada prediksi laba masa depan, dimana informasi laba masa depan ini digunakan bagi para investor untuk dijadikan pedoman dalam proses pengambilan keputusan melakukan investasi pada suatu perusahaan (Murwaningsari, 2014). Prediksi laba masa depan ini dapat diukur dengan future earnings response coefficient (FERC) yang merupakan model dari Collins et al. (1994) serta digunakan pengukuran tersebut oleh Tucker \& Zarowin (2006). Future earnings response coefficient dipengaruhi oleh beberapa faktor, diantaranya adalah corporate governance, dimana konsepsi corporate governance di korporasi dipengaruhi oleh kekuasaan atau kekuatan yang dimiliki pihak yang berkepentingan dalam entitas koperasi (Luckviarman, 2016:20). Salah satu mekanisme corporate governance adalah struktur kepemilikan, kepemilikan yang berpengaruh terhadap future earnings response coefficient adalah kepemilikan manajerial dan kepemilikan institusional. Kepemilikan manajerial yang tinggi akan memberikan motivasi bagi para manajer 
untuk meningkatkan laba di masa depan, begitu pula dengan kepemilikan institusional yang tinggi akan memberikan pengawasan kepada para manajer agar dapat meningkatkan nilai perusahaan yaitu laba masa depan.

Kepemilikan manajerial mempunyai peran yang sangat penting, dimana semakin tinggi kepemilikan manajerial, maka manajer akan lebih banyak menanggung konsekuensi ekonomi dari tindakan mereka, sehingga manajer akan berusaha untuk menahan diri menghamburkan kekayaan perusahaan atau pemegang saham, sehingga manajer akan lebih suka untuk meningkatkan kesejahteraan mereka sendiri (Al-Dhamari \& Ismail, 2014; Liu, 2016). Insentif bagi pemilik perusahaan yang menguasai jumlah saham yang besar untuk memonitor secara intens investasi yang dilakukan dengan asumsi bahwa tingkat pengendalian yang dilakukan akan meningkat sesuai besaran porsi saham yang dimiliki (Luckviarman, 2016:20). Penelitian Murwaningsari (2012) menyatakan semakin besar kepemilikan manajerial pada suatu perusahaan, maka manajemen akan berusaha memenuhi kepentingan para pemegang saham yaitu return. Return tersebut bisa laba masa sekarang dan laba masa depan seperti future earnings response coefficient.

Kepemilikan institusional memiliki peran yang penting dalam sebuah korporasi, karena besarnya kepemilikan institusional dapat meningkatkan efektivitas pengelolaan korporasi terhadap manajemen yang dapat dilihat pada pasar yang memberikan reaksi terhadap pengumuman laba (Sari et al., 2010). Penelitian Murwaningsari (2014) menunjukkan bahwa kepemilikan institusional berpengaruh positif terhadap future earnings response coefficient. Perusahaan yang memiliki kepemilikan institusional yang tinggi maka akan memberikan informasi laba masa depan yang jelas, hal tersebut dapat dilihat dari harga sahamnya. Semakin tinggi tingkat kepemilikan institusional akan semakin tinggi pula signal positif yang diberikan oleh investor institusional terhadap laba masa depan. Penelitian ini juga didukung penelitian Healy et al. (1999), Jiambalvo et al. (2002), Murwaningsari (2013), Al-Dhamari \& Ismail (2014).

Salah satu faktor yang dapat mempengaruhi dan memperkuat hubungan positif kepemilikan manajerial, kepemilikan institusional dan future earnings respose coefficient adalah adanya variabel moderasi yaitu kesempatan pertumbuhan, dimana jika kesempatan pertumbuhan besar maka manajer akan mendapat keamanan kerja, kompensasi, prestise dan pengeluaran diskresioner yang lebih besar. Penelitian Henny (2017) menyatakan bahwa kesempatan pertumbuhan berpengaruh positif terhadap future earnings response coefficient, dimana semakin tinggi kesempatan pertumbuhan suatu perusahaan maka semakin tinggi pula laba masa depan yang dilihat tingginya harga saham, hal tersebut merupakan signal positif bagi investor di pasar modal. Penelitian Henny (2017) juga didukung oleh penelitian Brown (2001) dan Murwaningsari (2013).

Kontribusi penelitian ini adalah untuk menunjukkan adanya peranan kepemilikan manajerial dan kepemilikan institusional serta kesempatan pertumbuhan dari suatu perusahaan manufaktur yang terdaftar di Bursa Efek Indonesia yang mempengaruhi prediksi laba masa depan yaitu future earnings response coefficient. Penelitian ini menggunakan variabel kepemilikan manajerial yang pertama kali digunakan dalam perusahaan manufaktur dan merupakan saran penelitian selanjutnya oleh Murwaningsari (2013). Penelitian ini juga menggunakan variabel kesempatan pertumbuhan yang merupakan pertama kali digunakan dalam perusahaan manufaktur di Indonesia sebagai variabel moderasi dari variabel dependen future earnings reponse coefficient dan variabel independen kepemilikan manajerial dan kepemilikan institusional. Perusahaan manufaktur yang digunakan dalam penelitian ini dikarenakan perusahaan manufaktur merupakan perusahaan yang paling banyak terdaftar di Bursa Efek Indonesia. 
Alasan pemilihan topik penelitian "Pengaruh kepemilikan manajerial dan kepemilikan institusional terhadap future earnings response coefficient dengan kesempatan pertumbuhan sebagai variabel moderasi" merupakan penelitian yang masih jarang dilakukan di Indonesia, karena penelitian mengenai future earnings response coefficient merupakan isu yang cukup baru.

Tujuan penelitian ini adalah untuk memperoleh bukti empiris mengenai: 1) Kepemilikan Manajerial berpengaruh positif terhadap Future Earnings Response Coefficient; 2) Kepemilikan Institusional berpengaruh positif terhadap Future Earnings Response Coefficient; 3) Kesempatan Pertumbuhan sebagai variabel moderasi memperkuat hubungan positif Kepemilikan Manajerial dan Future Earnings Response Coefficient; 4) Kesempatan Pertumbuhan sebagai variabel moderasi memperkuat hubungan positif Kepemilikan Institusional dan Future Earnings Response Coefficient.

Hasil penelitian ini diharapkan dapat memberikan manfaat: (1) Manfaat praktis, bagi investor manajerial dan institusional adalah membantu mempercepat proses pengambilan keputusan untuk melakukan investasi pada perusahaan manufaktur yang memberikan future earnings response coefficient tinggi serta diperkuat hubungan positifnya oleh variabel kesempatan pertumbuhan; (2) Manfaat teoritis, bagi akademisi diharapkan penelitian ini memberikan informasi tentang pengaruh corporate governance terhadap future earnings response coefficient dengan kesempatan pertumbuhan sebagai variabel moderasi. Selain itu, penelitian ini diharapkan dapat memberikan kontribusi sebagai bahan referensi untuk penelitian sejenis mengenai future earnings response coefficient.

\section{Tinjauan Pustaka \\ Teori Signal}

Menurut Ross (1977), teori signal mengemukakan bahwa agen perusahaan memberikan informasi kepada pemegang saham tentang nilai perusahaan di masa mendatang akan mengalami kenaikan, sehingga memberikan signal positif kepada pemegang saham. Signal positif ini akan di respon oleh pemegang saham dengan menambah investasinya kepada perusahaan, karena nilai perusahaan diprediksikan akan meningkat dengan adanya penambahan investasi yang dilakukan oleh pemegang saham (Manurung, 2012:112). Nilai perusahaan masa mendatang yang dimaksud adalah laba masa depan.

\section{Future Earnings Response Coefficient (FERC)}

Future earnings response coefficient merupakan prediksi laba masa depan yang dikembangkan oleh Collins et al. (1994) untuk mengetahui seberapa banyak informasi yang didapatkan dari laba masa depan dan perubahan dalam laba masa kini. Future earnings response coefficient ini merupakan prediksi hubungan antara laba masa depan (future earnings, laba masa kini (current earnings), dan laba masa lalu (past earnings). Faktor-faktor yang mempengaruhi future earnings response coefficient adalah kepemilikan manajerial, kepemilikan institusional yang dimoderasi oleh kesempatan pertumbuhan.

Berikut pengembangan hipotesis penelitian ini berdasarkan hasil penelitian terdahulu tersebut.

\section{Pengaruh kepemilikan manajerial terhadap future earnings response coefficient}

Kepemilikan manajerial mendorong pihak manajemen untuk meningkatkan return. Return perusahaan yang dimaksud adalah laba perusahaan, dimana semakin besar proporsi kepemilikan manajerial maka pihak manajemen akan berusaha seoptimal mungkin meningkatkan nilai perusahaan dengan memenuhi kepentingan investor atau pemegang saham termasuk pihak manajemennya sendiri sebagai pemilik saham perusahaan (Murwaningsari, 2012; Al-Dhamari \& Ismail, 2014; Liu, 2016). Hal ini berarti semakin tinggi kepemilikan manajerial maka investor 
memberikan signal positif terhadap peningkatan laba kejutan di masa depan yaitu future earnings response coefficient. Berdasarkan analisis di atas, maka hipotesisnya adalah :

$\mathrm{H}_{1}$ : Kepemilikan manajerial berpengaruh positif terhadap future earnings response coefficient

\section{Pengaruh kepemilikan institusional terhadap future earnings response coefficient}

Kepemilikan institusional berpengaruh positif terhadap future earnings respose coefficient dalam penelitian Murwaningsari (2013 \& 2014) menyatakan bahwa proporsi kepemilikan institusional perusahaan yang semakin tinggi akan memberikan informasi mengenai laba di masa depan yang terlihat dalam harga saham perusahaan tersebut. Hal ini dikarenakan kepemilikan institusional dapat mengawasi dan mencegah tindakan strategis yang dilakukan para manajer dalam mengungkapkan laba di masa depan (Karamanou \& Vafeas, 2005; Al-Dhamari \& Ismail, 2014). Semakin tinggi kepemilikan institusional akan memberikan signal positif terhadap peningkatan laba di masa depan. Berdasarkan analisis di atas, maka hipotesisnya adalah:

$\mathrm{H}_{2}$ : Kepemilikan institusional berpengaruh positif terhadap future earnings response coefficient

Kesempatan pertumbuhan sebagai variabel moderasi memperkuat hubungan positif kepemilikan manajerial dan future earnings response coefficient

Perusahaan yang memiliki kesempatan pertumbuhan yang tinggi akan meningkatkan laba kejutan yang positif dan hal ini merupakan signal positif bagi para pemegang saham di pasar modal yang akan terlihat pada harga suatu perusahaan meningkat pula (Brown, 2001; Murwaningsari, 2013; Henny, 2017). Salah satu pemegang saham perusahaan adalah pihak manajemen, dimana pihak manajemen akan cenderung meningkatkan nilai perusahaan dengan kesempatan pertumbuhan perusahaan yang cenderung naik, sehingga pihak manajemen akan berusaha mengutamakan kepentingan sebagai pemilik perusahaan dalam proporsi kepemilikan manajerial. Semakin tinggi kesempatan pertumbuhan maka akan memberikan signal positif yang kuat antara kepemilikan manajerial dan future earnings response coefficient. Berdasarkan analisis dan hasil penelitian di atas, maka hipotesisnya adalah:

$\mathrm{H}_{3}$ : Kesempatan pertumbuhan sebagai variabel moderasi memperkuat hubungan positif kepemilikan manajerial dan future earnings response coefficient

Kesempatan pertumbuhan sebagai variabel moderasi memperkuat hubungan positif kepemilikan institusional dan future earnings response coefficient

Kesempatan pertumbuhan merupakan hal yang diinginkan para investor, termasuk investor institusional, karena kesempatan pertumbuhan akan memberikan signal positif kepada para investor tentang informasi laba di masa depan (Brown, 2001; Murwaningsari, 2013; Henny, 2017). Semakin tinggi kesempatan pertumbuhan maka akan memberikan signal positif yang kuat antara kepemilikan institusional dan future earnings response coefficient, karena manajer dalam tindakannya akan diawasi oleh para investor institusional sehingga akan berhati-hati dalam mengambil keputusan dan berusaha meningkatkan nilai perusahaan. Berdasarkan analisis di atas, maka hipotesisnya adalah:

$\mathrm{H}_{4}$ : Kesempatan pertumbuhan sebagai variabel moderasi memperkuat hubungan positif kepemilikan institusional dan future earnings response coefficient 
Berikut digambarkan kerangka pemikiran berdasarkan hipotesis di atas:

Variabel Independen

\section{Variabel Dependen}

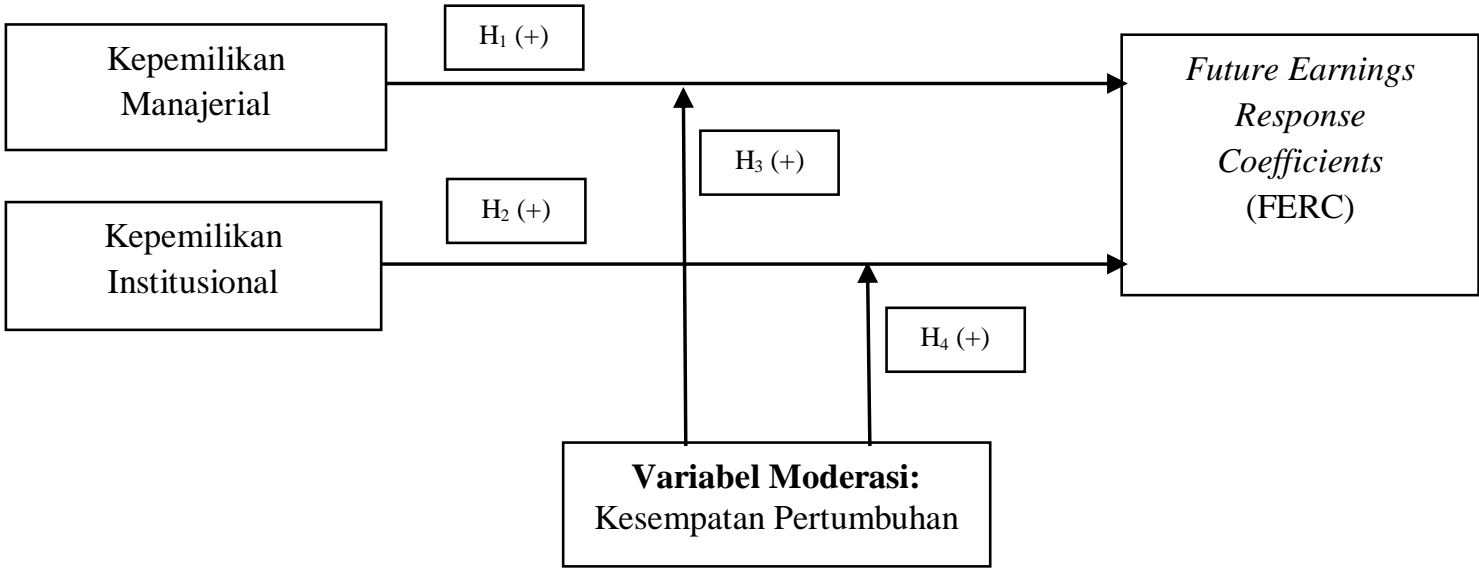

Gambar 1. Kerangka Pemikiran

\section{METODE PENELITIAN}

\section{Desain Penelitian}

Penelitian ini didesain menggunakan pendekatan kuantitatif dan data sekunder yang bersumber dari laporan keuangan perusahaan manufaktur yang terdaftar di Bursa Efek Indonesia periode pengamatan 2011-2014, dengan data yang diperlukan dari tahun 2010-2017. Data variabel independen (kepemilikan manajerial dan kepemilikan institusional) dan variabel moderasi (kesempatan pertumbuhan) menggunakan data sekunder periode pengamatan 2011-2014, sedangkan variabel dependen (future earnings response coefficient) menggunakan data sekunder periode 2010-2017. Data sekunder yang dikumpulkan merupakan data panel yang selanjutnya dilakukan analisis secara statistik dan mengambil kesimpulan dari hasil analisis statistik tersebut.

\section{Populasi, Sampel dan Metode Pengumpulan Sampel}

Populasi dalam penelitian ini adalah seluruh perusahaan manufaktur yang terdaftar di Bursa Efek Indonesia (BEI) pada periode tahun $2011 \mathrm{~s} / \mathrm{d}$ 2014, dengan data yang diperlukan untuk variabel dependen future earnings response coefficient dari tahun 2010 s/d 2017. Penentuan sampel dilakukan dengan purposive sampling method dengan menggunakan kriteria dalam pemilihan sampel. Prosedur pemilihan sampel dengan kriteria sebagai berikut: (1) Perusahaan manufaktur yang terdaftar di Bursa Efek Indonesia (BEI) pada periode tahun 2010 s/d 2017; (2) Perusahaan memiliki laba pada periode 2010 s/d 2017; (3) Perusahaan memiliki data lengkap periode tahun 2010 s/d 2017.

\section{Metode Analisis Data}

Analisis data yang digunakan moderated regression analysis dengan software pengolahan data SPSS (Ghozali, 2016:219). Analisis data akan dimulai dari analisis statistik deskriptif, uji asumsi klasik, uji normalitas, uji F, uji t, dan uji koefisien determinasi. Model regresi yang digunakan adalah:

$$
\mathrm{FERC}=\alpha+\beta_{1} \mathrm{KM}+\beta_{2} \mathrm{KI}+\beta_{3} \mathrm{KP}+\beta_{4} \mathrm{KM} \mathrm{KP}^{*}+\beta_{5} \mathrm{KI}^{*} \mathrm{KP}+\varepsilon
$$

Keterangan: $\mathrm{FERC}=$ Future earnings response coefficient; $\mathrm{KM}=$ Kepemilikan manajemen; $\mathrm{KI}$ $=$ Kepemilikan institusional; $\mathrm{KP}=$ Kesempatan pertumbuhan; $\mathrm{KM}^{*} \mathrm{KP}=$ Kepemilikan manajemen*Kesempatan pertumbuhan; $\mathrm{KI}^{*} \mathrm{KP}=$ Kepemilikan institusional*Kesempatan pertumbuhan; $\alpha=$ Konstanta; $\beta_{1}=$ Jika koefisien KM mengalami peningkatan/penurunan sebesar 1 maka FERC akan mengalami naik/turun sebesar $1 ; \beta_{2}=$ Jika koefisien KI mengalami 
peningkatan/penurunan sebesar 1 maka FERC akan mengalami naik/turun sebesar $1 ; \beta_{3}=\mathrm{Jika}$ koefisien KP mengalami peningkatan /penurunan sebesar 1 maka FERC akan mengalami naik/turun sebesar $1 ; \beta_{4}=$ Jika koefisien $\mathrm{KM}^{*} \mathrm{KP}$ mengalami peningkatan/penurunan sebesar 1 maka FERC akan mengalami naik/turun sebesar $1 ; \beta_{5}=$ Jika koefisien KI*KP mengalami peningkatan/penurunan sebesar 1 maka FERC akan mengalami naik/turun sebesar $1 ; \varepsilon=$ Error .

\section{Operasionalisasi Variabel}

Berikut Tabel 1 yang berisi variabel dependen, independen dan moderasi yang digunakan dalam penelitian ini.

Tabel 1. Tabel Operasional Variabel

\begin{tabular}{|c|c|c|c|c|}
\hline No & Variabel & Ukuran & Skala & Sumber \\
\hline 1 & $\begin{array}{l}\text { Dependen (Y): } \\
\text { Future Earnings } \\
\text { Response Coefficient } \\
\text { (FERC) }\end{array}$ & $R_{t}=b_{0}+b_{1} X_{t-1}+b_{2} X_{t}+b_{3} X_{t 3}+b_{4} R_{t 3}+\varepsilon_{t}$ & Rasio & $\begin{array}{l}\text { Tucker \& Zarowin } \\
\text { (2006), Murwaningsari } \\
\text { (2013 \& 2014), } \\
\text { Pradhana \& } \\
\text { Murwaningsari (2014) }\end{array}$ \\
\hline 2 & $\begin{array}{l}\text { Independen }\left(\mathrm{X}_{1}\right) \text { : } \\
\text { Kepemilikan } \\
\text { Manajerial }\end{array}$ & $\begin{array}{l}\text { (Jumlah saham kepemilikan manajerial / } \\
\text { jumlah saham yang beredar) x } 100 \%\end{array}$ & Rasio & Setyo $(2005)$ \\
\hline 3 & $\begin{array}{l}\text { Independen }\left(\mathrm{X}_{2}\right) \text { : } \\
\text { Kepemilikan } \\
\text { Institusional }\end{array}$ & $\begin{array}{l}\text { (Jumlah saham kepemilikan institusional / } \\
\text { Jumlah saham yang beredar) x } 100 \% \text {. }\end{array}$ & Rasio & Haruman (2008) \\
\hline 4 & $\begin{array}{l}\text { Moderasi: } \\
\text { Kesempatan } \\
\text { Pertumbuhan }\end{array}$ & $\begin{array}{l}\text { ((Penjualan bersih }(t)-\text { Penjualan bersih }(t- \\
\text { 1)) / Penjualan bersih }(t-1)) \times 100 \% \text {. }\end{array}$ & Rasio & $\begin{array}{l}\text { Prasetiono \& Pujiani } \\
\text { (2012) }\end{array}$ \\
\hline
\end{tabular}

\section{HASIL DAN PEMBAHASAN}

\section{Hasil}

Berdasarkan data yang diperoleh, perusahaan manufaktur yang memenuhi kriteria dalam penelitian ini adalah sebanyak 36 perusahaan. Dengan menggunakan data variabel independen (X) selama 4 tahun (tahun $2011 \mathrm{~s} / \mathrm{d}$ 2014), dan data variabel dependen (Y) selama 7 tahun (tahun 2010 s/d 2017) maka diperoleh sebanyak $36 \times 4=144$ data pengamatan menjadi 126 data pengamatan, karena ada data yang tidak normal. Kemudian data tersebut dilakukan pengujian statistik deskriptif, dan selanjutnya dilakukan uji normalitas dengan menggunakan One Sample Kolmogorov Smirnov Test yang menunjukkan hasil signifikansi 0,355>0,05, maka dapat disimpulkan data berdistribusi normal.

Selanjutnya uji statistik F pada dasarnya menunjukkan apakah semua variabel independen atau bebas yang dimasukkan dalam model mempunyai pengaruh secara bersama-sama terhadap variabel dependen/terikat (Ghozali, 2016:96). Berdasarkan hasil signifikansi yang ditunjukkan sebesar 0,022 < 0,05 bahwa Ho ditolak atau Ha diterima yang berarti bahwa variabel independen Kepemilikan Manajerial dan Kepemilikan Institusional, serta variabel moderasi yaitu Kesempatan Pertumbuhan secara simultan berpengaruh signifikan terhadap variabel dependen Future Earnings Response Coefficient. Sedangkan uji Statistik t pada dasarnya menunjukkan seberapa jauh pengaruh satu variabel penjelas/independen secara individual dalam menerangkan variasi variabel independen (Ghozali, 2016:97).

Berdasarkan hasil uji partial test (uji t) dapat dinyatakan model regresi dalam penelitian ini sebagai berikut: 
$\mathrm{FERC}=0,146070+0,000269(\mathrm{KM})+0,000212(\mathrm{KI})+0,000234(\mathrm{KP})+0,000020\left(\mathrm{KM}^{*} \mathrm{KP}\right)+$ $0,000005\left(\mathrm{KI}^{*} \mathrm{KP}\right)+\varepsilon$

Keterangan: FERC $=$ Future earnings response coefficient; $\mathrm{KM}=$ Kepemilikan manajemen; KI $=$ Kepemilikan institusional; $\mathrm{KP}=$ Kesempatan pertumbuhan; $\mathrm{KM}^{*} \mathrm{KP}=$ Kepemilikan manajemen*Kesempatan pertumbuhan; $\mathrm{KI}^{*} \mathrm{KP}=$ Kepemilikan institusional*Kesempatan pertumbuhan; $\varepsilon=$ Error.

Berdasarkan model regresi di atas maka dapat diartikan untuk angka-angka konstan dan koefisien tersebut serta hasil uji t adalah sebagai berikut.

a. Nilai konstan sebesar 0,146070 artinya jika KM, KI, KP, KM*KP dan KI*KP bernilai konstan (tetap), maka FERC sebesar 0,146070.

b. Koefisien regresi KM sebesar 0,000269 menunjukkan bahwa pengaruh KM terhadap FERC adalah positif. Berdasarkan nilai koefisien regresi tersebut dapat disimpulkan jika KM mengalami peningkatan/penurunan sebesar 1 maka FERC akan mengalami naik/turun sebesar 0,000269. Pengaruh tersebut tidak signifikan pada tingkat 5\% atau dengan kata lain Ho diterima atau Hal ditolak artinya tidak terdapat pengaruh dan signifikan KM terhadap FERC.

c. Koefisien regresi KI sebesar 0,000212 menunjukkan bahwa pengaruh KI terhadap FERC adalah positif. Berdasarkan nilai koefisien regresi tersebut dapat disimpulkan jika KI mengalami peningkatan/penurunan sebesar 1 maka FERC akan mengalami naik/turun sebesar 0,000212. Pengaruh tersebut tidak signifikan pada tingkat 5\% atau dengan kata lain Ho diterima atau $\mathbf{H a} 2$ ditolak artinya tidak terdapat pengaruh dan signifikan KI terhadap FERC.

d. Koefisien regresi KP sebesar 0,000234 menunjukkan bahwa pengaruh KP terhadap FERC adalah positif. Berdasarkan nilai koefisien regresi tersebut dapat disimpulkan jika KP mengalami peningkatan/penurunan sebesar 1 maka FERC akan mengalami naik/turun sebesar 0,000234. Pengaruh tersebut tidak signifikan pada tingkat 5\% atau dengan kata lain Ho diterima atau Ha3 ditolak artinya tidak terdapat pengaruh dan signifikan KP terhadap FERC.

e. Koefisien regresi variabel interaksi $\mathrm{KM}^{*} \mathrm{KP}$ sebesar 0,000020 menunjukkan bahwa pengaruh $\mathrm{KM}^{*} \mathrm{KP}$ terhadap FERC adalah positif. Berdasarkan nilai koefisien regresi tersebut dapat disimpulkan jika $\mathrm{KM}^{*} \mathrm{KP}$ mengalami peningkatan/penurunan sebesar 1 maka FERC akan mengalami naik/turun sebesar 0,000020. Pengaruh tersebut signifikan pada tingkat 5\% atau dengan kata lain Ho ditolak atau Ha4 diterima artinya terdapat pengaruh dan signifikan interaksi $\mathrm{KM}^{*} \mathrm{KP}$ terhadap FERC.

f. Koefisien regresi variabel interaksi KI*KP sebesar 0,000005 menunjukkan bahwa pengaruh $\mathrm{KI}^{*} \mathrm{KP}$ terhadap FERC adalah positif. Berdasarkan nilai koefisien regresi tersebut dapat disimpulkan jika KI*KP mengalami peningkatan/penurunan sebesar 1 maka FERC akan mengalami turun/naik sebesar 0,000005. Pengaruh tersebut signifikan pada tingkat 5\% atau dengan kata lain Ho ditolak atau Ha5 diterima artinya terdapat pengaruh dan signifikan interaksi KI*KP terhadap FERC.

Hasil uji koefisien determinasi menunjukkan nilai $R$ squared sebesar 0,102, angka ini menunjukkan Kepemilikan Manajerial, Kepemilikan Institusional dan Kesempatan Pertumbuhan mampu menjelaskan variasi 10,2\% dari variabel Future Earnings Response Coefficient. Untuk Nilai adjusted $R$ square sebesar 0,065, angka ini menunjukkan bahwa sebesar 6,5\% dari Future Earnings Response Coefficient dapat dijelaskan oleh Kepemilikan Manajerial, Kepemilikan Institusional dan Kesempatan Pertumbuhan sedangkan sisanya dijelaskan oleh variabel lain diluar penelitian ini. 


\section{Pembahasan}

Hasil hipotesis bersumber dari pengolahan data uji statistik, dimana hasil uji ini memberikan gambaran apakah hipotesis diterima (gagal ditolak) atau ditolak. Berikut rangkuman hasil hipotesis tersebut terlihat pada Tabel 2:

Tabel 2. Hasil Hipotesis

\begin{tabular}{clccc}
\hline \multirow{2}{*}{ No Hipotesis } & \multicolumn{1}{c}{ Nilai Uji } & Keterangan \\
\cline { 2 - 4 } & \multicolumn{1}{c}{$\begin{array}{c}\text { Kepemilikan Manajerial berpengaruh positif terhadap Future } \\
\text { Earnings Response Coefficient }\end{array}$} & 0,000269 & 0,316 & Ditolak \\
\hline 2 & $\begin{array}{l}\text { Kepemilikan Institusional berpengaruh positif terhadap Future } \\
\text { Earnings Response Coefficient }\end{array}$ & 0,000212 & 0,222 & Ditolak \\
\hline 3 & $\begin{array}{l}\text { Kesempatan Pertumbuhan sebagai variabel moderasi } \\
\text { memperkuat hubungan positif Kepemilikan Manajerial dan } \\
\text { Future Earnings Response Coefficient }\end{array}$ & 0,000020 & 0,002 & Diterima \\
\hline 4 & $\begin{array}{l}\text { Kesempatan Pertumbuhan sebagai variabel moderasi } \\
\text { memperkuat hubungan positif Kepemilikan Institusional dan } \\
\text { Future Earnings Response Coefficient }\end{array}$ & 0,000005 & 0,004 & Diterima \\
\hline
\end{tabular}

Sumber: Hasil Pengolahan Data

Hasil pengujian hipotesis pertama dan kedua menunjukkan bahwa variabel Kepemilikan Manajerial memiliki signifikansi 0,316 terhadap Future Earnings Response Coefficient dan variabel Kepemilikan Institusional memiliki signifikansi 0,222 terhadap Future Earnings Response Coefficient. Hasil ini menunjukkan bahwa variabel Kepemilikan Manajerial dan Kepemilikan Institusional tersebut secara statistik tidak berpengaruh terhadap Future Earnings Response Coefficient. Hasil penelitian ini tidak mendukung hasil penelitian Karamanou \& Vafeas (2005), Murwaningsari (2012, 2013 \& 2014), Al-Dhamari \& Ismail (2014), dan Liu (2016). Hal ini dapat disimpulkan bahwa hipotesis pertama dan kedua menunjukkan tidak berpengaruh signifikan secara langsung dikarenakan investor atau pemegang saham baik dari manajerial maupun institusional tidak berfokus terhadap future earnings response coefficient, melainkan pengawasan terhadap keputusan dan aksi yang dilakukan oleh pimpinan perusahaan tertinggi yang akan berdampak buruk kepada para investor.

Hasil pengujian hipotesis ketiga menunjukkan bahwa Kesempatan Pertumbuhan sebagai variabel moderasi memiliki signifikansi 0,002 dalam memperkuat hubungan Kepemilikan Manajerial dan Future Earnings Response Coefficient. Hasil ini menunjukkan bahwa variabel Kesempatan Pertumbuhan tersebut secara statistik berpengaruh signifikan dalam memperkuat hubungan positif Kepemilikan Manajerial dan Future Earnings Response Coefficient. Hasil penelitian ini mendukung hasil penelitian Brown (2001), Murwaningsari (2013), Henny (2017) menunjukkan pihak manajemen akan cenderung meningkatkan nilai perusahaan dengan kesempatan pertumbuhan perusahaan yang cenderung naik, sehingga pihak manajemen akan berusaha mengutamakan kepentingan sebagai pemilik perusahaan dalam proporsi kepemilikan manajerial.

Hasil pengujian hipotesis keempat menunjukkan bahwa Kesempatan Pertumbuhan sebagai variabel moderasi memiliki signifikansi 0,004 dalam memperkuat hubungan Kepemilikan Institusional dan Future Earnings Response Coefficient. Hasil ini menunjukkan bahwa variabel Kesempatan Pertumbuhan tersebut secara statistik berpengaruh signifikan dalam memperkuat 
hubungan Kepemilikan Institusional dan Future Earnings Response Coefficient. Hasil penelitian ini mendukung hasil penelitian Brown (2001), Murwaningsari (2013), dan Henny (2017), yang menyatakan bahwa kesempatan pertumbuhan merupakan hal yang diinginkan para investor, termasuk investor institusional, karena kesempatan pertumbuhan akan memberikan signal positif kepada para investor tentang informasi laba di masa depan.

\section{KESIMPULAN DAN SARAN}

\section{Kesimpulan}

Peran kesempatan pertumbuhan sebagai variabel moderasi memperkuat hubungan positif variabel kepemilikan manajerial dan kepemilikan institusional terhadap future earnings response coefficient perusahaan manufaktur, dimana pihak manajemen akan cenderung meningkatkan nilai perusahaan dengan kesempatan pertumbuhan perusahaan yang cenderung naik, sehingga pihak manajemen akan berusaha mengutamakan kepentingan sebagai pemilik perusahaan dalam proporsi kepemilikan manajerial dan sebagai manajer yang berhati-hati dalam mengambil keputusan serta berusaha meningkatkan nilai perusahaan bagi investor institusional.

Penelitian ini memiliki keterbatasan. Pertama, penelitian ini tidak memasukkan seluruh perusahaan yang terdaftar di Bursa Efek Indonesia. Kedua, penelitian ini hanya menggunakan variabel kepemilikan manajerial dan kepemilikan institusional dalam menguji pengaruh langsung terhadap future earnings response coefficient, dan variabel kesempatan pertumbuhan sebagai variabel moderasi. Ketiga, penelitian ini menggunakan SPSS dalam pengolahan datanya. Keempat, hasil adjusted $R$ square penelitian ini menunjukkan persentase yang sangat kecil berarti masih banyak variabel lain yang dapat mempengaruhi future earnings response coefficient.

\section{Saran}

Saran untuk penelitian berikutnya adalah Pertama, memasukkan seluruh perusahaan yang terdaftar di Bursa Efek Indonesia sehingga hasil penelitiannya dapat digeneralisasi dan lebih komprehensif. Kedua, penelitian berikutnya dapat menambahkan faktor yang lain seperti kepemilikan asing sebagai variabel independen, serta leverage sebagai variabel moderasi sehingga hasil penelitian dapat lebih tepat. Ketiga, penelitian berikutnya dapat menggunakan Eviews dalam pengolahan data panel. Keempat, untuk meningkatkan adjusted $R$ square atas pengaruh terhadap future earnings response coefficient dapat dilakukan dengan cara meneliti variabel independen yang tepat.

\section{Ucapan Terima Kasih (Acknowledgement)}

Terima kasih kepada Lembaga Penelitian dan Pengabdian kepada Masyarakat Universitas Tarumanagara yang telah memberikan kontribusi dana untuk penelitian ini dan mahasiswa yang telah memberikan kontribusi dalam pengumpulan data (Lucky Suvia, Vivien, Anggraini dan Cynthia), serta asisten peneliti yang telah memberikan kontribusi dalam input data yang bermakna bagi penelitian ini.

\section{REFERENSI}

Al-Dhamari, R. A. \& Ismail K. N. I. K. (2014). An Investigation into the Effect of Surplus Free Cash Flow, Corporate Governance and Firm Size on Earnings Predictability. International Journal of Accounting and Information Management, 22(2), 118-133.

Brown, L. (2001). A Temporal Analysis of Earnings Surprises: Profits and Losses. Journal of Accounting Research, 39, 221-241. 
Collins, D. W., Kothari, S. P. Shanken, J. \& Sloan, R. (1994). Lack of Timeliness and Noise as Explanations for the Low Contemporaneous Return-Earnings Association. Journal of Accounting and Economics, 18(14), 289-324.

Ghozali, I. (2016). Aplikasi Analisis Multivariate dengan Program IBM SPSS 23. Edisi 8. Badan Penerbit Universitas Diponegoro, Semarang.

Haruman, T. (2008). Pengaruh Struktur Kepemilikan Terhadap Keputusan Pendanaan (Perspektif Agency Theory). Simposium Nasional Akuntansi XI (SNA XI), Makasar, 27 November 2008.

Healy, P. M., Myers, S. C., \& Howe, C. D. (1999). R \& D Accounting and the Trade Off between Relevance and Objectivity. Journal of Accounting Research, 40(3), 677-710.

Henny. (2017). Pengaruh Public Ownership dan Growth Opportunity Terhadap Leverage dan Future Earnings Response Coefficient. Jurnal Muara Ilmu Ekonomi dan Bisnis, 1(1), 135-144.

Jiambalvo, J., Rajgopal, S., \& Venkatachalam, M. (2002). Institutional Ownership and the Extent to which Stock Prices Reflect Future Earnings. Contemporary Accounting Research, 19(1), 117-145.

Karamanou, I. \& Vafeas, N. (2005). The Association between Corporate Boards, Audit Committees, and Management Earnings Forecasts: An Empirical Analysis. Journal of Accounting Research, 43(3), 453-486.

Liu, S. (2016). Ownership Structure and Analysts' Forecast Properties: A Study of Chinese Listed Firms. Corporate Governance, 16(1), 54-78.

Luckviarman, N. (2016). Corporate Governance: Menuju Penguatan Konseptual dan Implementasi di Indonesia. PT Era Adicitra Intermedia, Solo.

Manurung, A. D. (2012). Konsep dan Empiris Teori Investasi. Percetakan STIEP Press, Jakarta.

Murwaningsari, E. (2012). Pengaruh Struktur Kepemilikan Terhadap Return Saham. Media Riset Akuntansi, Auditing \& Informasi, 12(1), 45-60.

Murwaningsari, E. (2013). Pengaruh Kesempatan Pertumbuhan dan Investasi Jangka Panjang Terhadap Leverage dan Future Earnings Response Coefficient. Media Riset Bisnis \& Manajemen, 13(1), 1-19.

Murwaningsari, E. (2014). Kepemilikan Institusional dan Kualitas Audit Terhadap Pengungkapan Informasi dan Future Earnings Response Coefficient. Jurnal Keuangan dan Perbankan, 18(2), 161-171.

Pradhana, E. P. M. \& Murwaningsari, E. (2014). Pengaruh Market Power dan Corporate Governance Terhadap Future Earnings Response Coefficient Pada Perusahaan di Bursa Efek Indonesia. E-Journal Akuntansi Trisakti, 1(1), 1-19.

Prasetiono \& Pujiani. (2012). Analisis Pengaruh Return On Assets, Sales Growth, Struktur Aset, Firm Size, dan Investment Opportunity terhadap Financial Leverage. Diponegoro Journal of Management, 1(1), 158-171.

Ross, S. A. (1977). Dtermination of Financial Structure: The Incentive-Signalling Approach. The Bell Journal of Economics 8, 23-40.

Sari, R. N., Anugerah, R., \& Dwiningsih, R. (2010). Pengaruh Struktur Kepemilikan, Kualitas Audit, dan Ukuran Perusahaan Terhadap Transparansi Informasi. Jurnal Pendidikan Ekonomi dan Bisnis, 2(3), 326-335.

Setyo, G. B. B. (2005). Pengaruh Mekanisme Corporate Governance Terhadap manajemen Laba dan Dampaknya Pada Kualitas Laba. Jurnal Akuntansi, IX.

Tucker, W. J. \& Zarowin, P. A. (2006). Does Income Smoothing Improve Earnings Informativeness?. The Accounting Review, 81(1), 251-270. 